Original Research Paper

\title{
Financial Development and Economic Growth in Nepal: New intuitions from a Time Series Causality Method
}

\author{
${ }^{1}$ Uttam Paudel, ${ }^{2}$ Satish Chandra Bhatta and ${ }^{3}$ Umesh Khatri \\ ${ }^{1}$ Tribhuvan University, Kathmandu, Nepal \\ ${ }^{2}$ Shodhshala Center for Policy Studies, Kathmandu, Nepal \\ ${ }^{3}$ USAID, Kathmandu, Nepal
}

Article history

Received: 16-08-2017

Revised: 25-01-2018

Accepted: 26-03-2018

Corresponding Author:

Umesh Khatri

USAID, Kathmandu, Nepal

Tel: +977-9841644978

Email:khatriumesh000@gmail.com

\begin{abstract}
Generalized empirical evidences about impact and direction of causality between financial development and economic growth ignoring the differences of structure and other factors seem less effective to understand the contributions of financial as well as real sector development to economic growth by country specific factors in Nepal. This paper has established the short run or long run relationship and the direction of causality between financial and real sector development with economic growth. For the study purpose, time-series data covering the period of 1975 to 2015 were used considering whole financial system in Nepal as population and financial intermediation as sample for the study. E-Views 9 was used to obtain the results of Unit root test, Engle-Granger co-integration test, Error correction model and Granger causality test. Results conclude that although finance-led growth yields positive consequences, real sectors indicator like consumer price index (CPI) has more impact on real gross domestic product (GDP), a proxy of economic growth, than financial development indicators (M2Y, CPY) in Nepal. This study also predicts negative co-integrating relationship between trade openness and GDP.Bidirectional causality between broad money to GDP ratio and real GDP, and unidirectional causality of PIY and CPI with positive role upon GDP suggesting urgent need of contractionary fiscal and monetary policies to induce private sector investment in GDP.
\end{abstract}

Key words: Economic Growth, Financial Development, Co-Integration and Causality, Nepal

\section{Introduction}

Efficient financial system is a potential driver for an economy to enhance the rate of capital accumulation for sustainable and long-run economic growth (Rousseau and Wachtel, 2011). The efficacy of financial system to reduce information and transaction costs plays an important role in determining the rate of savings, investment decisions, technological innovations and hence the rate of economic growth (North, 1987; Arrow and Kruz, 2013). The relationship between financial development and economic growth has been an extensive issue of arguments posed on international literatures at both theoretical and empirical levels (Menyah et al., 2014).

The development of endogenous growth theory since late 1980 s has been continuously directing the multidimensional way for concocting new growth theories and its determinants. Despite its tremendous importance in economic policy formulation and implication, there is a lack of attention given to this subject in Nepal by academicians and policy makers. Thus a scientific endeavor seems mandatory to explore some ideas that will be instrumental to depict importance of financial sector development to economic growth.

Though economic liberalization and structural reforms of early-90s set the track for free trade but due to the inefficiency of the Nepalese economy especially the manufacturing and service sectors' poor performance, Nepal remains unable to foster economic development as compared to rest of the world (Asia, 2014). In this regard, the financial sector which has grown in both quantity and quality can be the engine of finance-led growth that can create investment friendly environment to encourage the investment and growth (Rousseau and Wachtel, 2011; Gautam, 2014).

The economic growth of Nepalese economy for several decades has been sluggish at around $4 \%$ average annual growth (Asia, 2014). Though the share of agriculture sector 
is diminishing and service sector is growing after the financial liberalization of the $90 \mathrm{~s}$, the traditional monsoonreliant agriculture sector still occupies the major chunk in the economy (Timsina, 2014; Maskay, 2016). Lack of: Capital formation and resource mobilization, investment in productive sector, income equality, formal and feasible financial access has been the major problems that halts the economic growth and prosperity for decades in developing countries (Levine, 1997).

Some literatures conveyed significant positive relation between finance and growth (Thiel and Thiel, 2001; Team and By, 2013; Gautam, 2014) and other recent study in contrast described the weak or insignificant relationship between financial development and economic growth (Samargandi et al., 2015). Prior studies commonly generalized the relationship between finance and growth ignoring the differences of structure and other essential factors that may vary country wise. Ergo, it might not be sage to put any outlook regarding the impact of financial sector on economic growth based on such generalized empirical results. Further, it seems mandatory to carry out a study to understand the contributions of financial development to economic growth being country specific by using time series data. However, the impact and direction of causality between finance and growth still ruins an arguable concern in the literature (Jin, 2010).

This paper aims to identify the relationship of financial and real sector development with economic growth in short run and long run. Moreover, an unreached area of researcher about the direction of causality between proxies of financial development and economic growth has explored in this study.

\section{Research Methodology}

\section{Research Design}

Both qualitative and quantitative research design are employed on secondary time-series data covering the period of 1975 to 2015 from various reliable sources such as Economic Survey of Ministry of Finance, Banking and Financial Statistics 2015, NRB, National Accounts of Nepal, CBS, GON, Quarterly Economic Bulletin 2016, Monetary Policy 2015, Previous Research, Books, Dissertations and Articles. The whole financial system in Nepal considered the population and financial intermediation as sample for the study. The study is primarily related with the macroeconomic variables like; Gross Domestic Product (GDP), broad money, domestic credit, private sector credit, total assets, deposit and credit of Commercial Banks and other BFIs and NBFIs including indicators of capital market. For the fulfillment for study purpose, EViews 9 was used to obtain the results of Unit root test, Engle-Granger co-integration test, Error correction model and Granger causality test.

\section{Description of Variables Used}

1. Financial Development Indicators (FD): It represents the independent variables used in the model. The ratios of FD indicators are deflated into real term and then converted into natural logarithmic form:

i) Broad money stock to GDP (M2Y): It is the leading indicator of monetization in the economy and shows the real size of the financial sector in the country (De Gregorio and Guidotti, 1995). The liquid liabilities/broad money to GDP ratio (M2Y) is used as a measure of financial depth and overall size of the financial intermediaries (King and Levine, 1993)

ii) Private sector credit to GDP (CPY): The flow accurately represents the actual volume of funds channeled into private sector from banks and financial institutions and indicates actual financial intermediation in the country. The ratio of credit to the private sector to GDP (CPY) is used as a measure of financial depth and banking development. It reflects the activity of the financial sector (Levine and Zervos, 1996)

2. Economic Growth Variables (GDP): As dependent variable in the model we have used the growth in GDP that indicates real sector growth in constant prices

3. Real Sector Growth Variables (X): As independent variables we have also used set of real sector growth indicators to capture the common determinants of economic growth. All control variables are used in a ratio form except $\mathrm{CPI}$ :

i) Private Investment to GDP (PIY): It is the ratio of private gross fixed capital formation to GDP

ii) Trade Openness to GDP (TOY): It is defined as the ratio of the sum of total exports plus imports to GDP

iii) Consumer Price Index (CPI): The model included inflation rate to control for price distortions during the study period. Here, inflation is measured as the annual percentage change in the CPI

\section{Model Specification}

A multivariate regression model seemed preferable to test the significance of financial development and economic growth. The following specification has postulated to explain possible association between financial development and economic growth in Nepal:

$R G D P=f(M 2 Y, C P Y, P I Y, T O Y, C P I)$ 
Where:

$R G D P$ : Real gross domestic product

$M 2 Y: \quad$ Ratio of broad money to GDP ratio

$C P Y: \quad$ Private credit to GDP ratio

$P I Y: \quad$ Ratio of private investment to GDP

TOY: $\quad$ Ratio of trade openness to GDP

CPI: Annual average consumer price index

Similarly, the econometric multivariate regression model from Equation (i) in natural logarithmic form becomes:

$$
\begin{aligned}
\operatorname{LNRGDP}_{t}= & \alpha_{0}+\beta_{1} L N M 2 Y_{t}+\beta_{2} L N C P Y_{t} \\
& +\beta_{3} L N P I Y_{t}+\beta_{4} L N T O Y_{t}+\beta_{5} L N C P I_{t}+\varepsilon_{t}
\end{aligned}
$$

Where:

$$
\begin{aligned}
& \alpha_{0} \quad=\text { Comstant (intercept) } \\
& \beta_{i} \quad=\text { Cofficient of explanatory variable } \\
& \varepsilon_{t} \quad=\text { Error term at same } t \text { (havezero mean }
\end{aligned}
$$

$L N R G D P_{t}=$ Natural logarithm of RGDP at $t$ (depentent variable)

$L N M 2 Y_{t}=$ Natural logarithm ratio of broad money to GDP at $t$

$L N C P Y_{t}=$ Natural logarithm ratio of claims on private sector to GDP at $t$

$L N P I Y_{t}=$ Natural logarithm ratio of private investment to GDP at $t$

$L_{N T O Y_{t}}=$ Natural logarithm ratio of trade openness to GDP at $t$

$L N C P I_{t}=$ Natural logarithm of annual average consumer price index at $t$

Precisely, an implicit form of model (ii) can be expressed as:

$$
L N R G D P_{t}=\alpha_{0}+\beta_{1} F D_{t}+\beta_{2} X_{t}+\varepsilon_{t}
$$

Where:

$F D_{t}=$ FD indicators (explanatory variables) at $t$

$X_{t}=$ Real sector growth indicators (control variables) at $t$

\section{Unit Root Tests}

The first step in building dynamic econometric model entails a thorough investigation of the characteristics of individual time series variables involved (Enders, 2014). Assumption for this test is overall FD has positive impact on economic growth or vice-versa. In order to avoid the problem of spurious regression, unit root test, as developed by Nelson and Plosser (1982), is used in examining the stationary of a time series. To this end, Augmented Dickey Fuller test (ADF test) is used:

$$
\Delta Y_{t}=\alpha_{0}+\alpha_{1} t+\phi Y_{t-i}+\sum \psi \Delta Y_{t-1}+\varepsilon_{t}
$$

Where:

$\mathrm{Y}=$ The variable under consideration

$\Delta=$ The first difference operator, $t$ captures time trend

$\varepsilon_{t} \quad=$ A random error

$\alpha_{0}, \alpha_{1}, \psi=$ The parameter to be estimated. Null hypothesis will not be rejected if $\phi=0$, this concludes the series under consideration has a unit root and is therefore non-stationary

\section{Engle Granger Co-integration Test}

Engle and Granger (1987) formulated one of the first tests of co-integration. This test has the advantage that it is intuitive and easy to perform. The first step starts by estimating co-integrating regression of the variables as:

$$
\begin{aligned}
& L N R G D P_{t}=\beta_{1}+\beta_{2} L N R G D P_{t}+\beta_{3} L N M 2 Y_{t}+\beta_{4} L N C P Y_{t} \\
& +\beta_{5} L_{N P I Y_{t}}+\beta_{6} \text { LNTOY }_{t}+\beta_{7} \text { LNCPI }_{t}+u_{t}
\end{aligned}
$$

In this regression we assumed that all variables are integrated of order one $I(1)$ and might co-integrate to form a stationary relationship and thus have a stationary residual term as:

$$
\begin{aligned}
\hat{u}_{t}= & L N R G D P_{t}-\beta_{1}-\beta_{2} L N R G D P_{t} \\
& -\beta_{3} L N M 2 Y_{t}-\beta_{4} L N C P Y_{t}-\beta_{5} L N P I Y_{t} \\
& -\beta_{6} L N T O Y_{t}-\beta_{7} L N C P I_{t}-u_{t}
\end{aligned}
$$

This equation represents the assumed meaningful economic interpretation of steady state or equilibrium relationship among the variables. If the variables are cointegrated, they will show the common trend and also form a stationary relationship in the long run between the variables. Furthermore, under the co-integration approach, due to the properties of super converge, the estimated parameters can be viewed as correct estimates of the long-run steady state parameters and the residual series can be used as an error correction term in an Error Correction Model (ECM). The second step is to do a unit root test of the residual series obtained from the cointegrating regression above. For this purpose, we set up a unit root test i.e., ADF test of residual series as:

$$
\Delta \hat{u}=\alpha+\pi \hat{u}_{t-1}+\sum_{i=1}^{k} \gamma_{i} \Delta \hat{u}_{t-i}+v_{t}
$$

where, the constant term $\alpha$ is used to improve the efficiency of the estimated results. Under the assumption of null hypothesis of no co-integration among the variables, the estimated residual is $I(1)$ and all parameters are zero in the long run. Also, finding a significant $\pi$ implies co-integration between variables. When the dependent variable is integrated along with at 
least one regress or of the identical order, then cointegration indicates a stationary $I(0)$ residual. Asymptotically, the test is independent of which variable occurs on the left hand side of the co-integrating regression. Taking one variable on the left hand side the co-integrating vector are assumed be normalized around that variable, indirectly we assume that the normalization relates to some eloquent long-run economic relationship.

\section{Error Correction Model (ECM)}

To correct short run disequilibrium with the rate of adjustment and to reveal the short-run relationship among variables, the co-integration term called error correction term is used under ECM framework since the deviation from long-run equilibrium is corrected gradually through a series of partial short-run adjustments.

The error term in the co-integrated regression equation is called equilibrium error term. This error term is used to tie the short run behavior of the dependent variable to its long run value. Specifically, the major use of it is for amending disequilibrium and testing for long and short-run causality among co-integrated variables.

In our model if both the variables real GDP and FD are co-integrated then there is a long run relationship between economic growth and financial development. Accordingly, for the short-run relationship between these variables ECM is conducted under the framework of cointegrating relationship.

In our model, according to Engle and Granger (1987), the ECM can be specified as follows in case of two pairs of test variables:

$$
\begin{aligned}
& \Delta L N R G D P_{t}=\omega_{1} Z_{t-1}+\alpha_{1} \Delta F D_{t}+\alpha_{2} \Delta X_{t}+U_{1 t} \\
& \Delta F D_{t}=\omega_{2} Z_{t-1}+\beta_{1} \Delta L N R G D P+\alpha_{2} \Delta X_{t}+U_{2 t}
\end{aligned}
$$

\section{Interpretations}

- Statistical significance tests are conducted on each of the lagged $Z_{t}$ term in Equations viii and ix

- The coefficient of $Z_{t}$ reflect the short run disequilibrium in the model

- The parameters $\omega_{1}$ and $\omega_{2}$ are the speed of adjustment parameters in Equation viii and ix when there is a discrepancy from long-run equilibrium

Alternatively, the ECM used in this study can be specified explicitly as follows:

$$
\begin{aligned}
& \Delta L N R G D P_{t}=\alpha_{0}+\sum_{i=0}^{m} \beta_{1 i} \Delta L N R G D P_{t-i} \\
& +\sum_{i=0}^{n} \beta_{2 i} \Delta L N M 2 Y_{t-i}+\sum_{i=0}^{q} \beta_{3 i} \Delta L N C P Y_{t-i} \\
& +\sum_{i=0}^{q} \beta_{4 i} \Delta P I Y_{t-i}+\sum_{i=0}^{q} \beta_{5 i} \Delta T O Y_{t-i} \\
& +\sum_{i=0}^{q} \beta_{6 i} \Delta C P I_{t-i}+\omega \varepsilon_{t-1}
\end{aligned}
$$

where, $\beta_{1}, \beta_{2}$ and $\beta_{3}$ are the coefficients of the lagged first difference variables providing the short run dynamics of the model. $\omega$ is the speed of adjustment parameter of $\left(\varepsilon_{t-1}\right)$ ECM which shows the divergence/convergence towards the long run equilibrium. Positive value of $\omega$ indicates divergence and negative value (desirable) indicates convergence.

\section{Granger Causality Test}

According to Granger, if a past value of $X$ improves the prediction of $Y$ with statistical significance, then we can conclude that $X$ "Granger Causes" $Y$ (Engle and Granger, 1987). In our case, if $X_{t}$ only causes $Y_{t}$ with no reciprocal effect from $Y_{t}$, then there is unidirectional causality. If the causality runs both ways there is bidirectional causality i.e., $X_{t} \rightarrow Y_{t}$ and $Y_{t} \rightarrow X_{t}$. Latter Engle and Granger developed the concept of co-integration stating that if two variables are co-integrated, there is the certainty of causal relation at least in one direction.

\section{Interpretations}

- If the coefficient of $\alpha_{1 i}$ is statistically significant but $\beta_{1 i}$ is not statistically significant, then LNRGDP is said to have been caused by FD (unidirectional causality)

- Reverse causality - holds if coefficients of $\beta_{2 i}$ are statistically significant while $\alpha_{2 i}$ is not. [i.e., $F D=f$ $\left.\left(L N R G D P_{t}\right)\right]$

- But if both $\beta_{2 i}$ and $\alpha_{2 i}$ are statistically significant, the causality runs both ways (bi-directional causality)

\section{Results}

Table 1 shows that LNRGDP in level form accept the null hypothesis of unit root since test-statistic is lower than its critical value and p-value greater than $5 \%$. After first differencing, null hypothesis of unit root is rejected with greater critical value -6.046 (trend) and -5.842 (trend and intercept) with significant p-value at $1 \%$, meaning that LNRGDP is stationary in first difference being integrated of order one i.e., I(1). Likewise, LNM2Y, LNCPY, LNTOY, LNPIY and LNCPI also have a unit root in level but all these variables are significant at $1 \%$ and integrated of order one in the first differenced form. Therefore, we can apply EngleGranger Co-integration test to study the co-integrating relationship among these variables.

\section{Unit Root Test of OLS}

One of the FD indicator, CPY is positively associated with real GDP for long run being statistically significant at $1 \%$ level while another variable $\mathrm{M} 2 \mathrm{Y}$ is not 
statistically significant. Meanwhile, remaining independent variables of the real sector economy (CPI and PIY have positive association with GDP for the long run but TOY has inverse relationship with GDP) shows very small p-values $(0.000)$ depicting the statistical significance of regression coefficients at less than $1 \%$ level. As all the independent variables except M2Y shows statistically significant results with higher $\mathrm{R}^{2}$ (0.998) and relevant D-W test value (1.613) and also the residual diagnostic tests showing: No autocorrelation (from Correlogram test with the acceptance of null hypothesis having insignificant p-values), normal distribution (as Normality test gives Jarque-Bera 3.69 with p-value 0.15 ), no serial correlation (as LM test shows F-stat 1.26 having p-value 0.26 ) and no heteroscedasticity (as Breush-Pagan-Godfrey test shows F-stat 1.10 having $0.37 \mathrm{p}$-value), the study accepts present model as it satisfied the OLS properties.

\section{Unit Root Test of Residual Series}

The residual series $\left(\varepsilon_{t}\right)$ in our OLS model is found stationary at level from the result in above Table 2 so it further validated the stationary of the model. Hence, we can accept the model as there is long-run equilibrium relationship between dependent and independent variables in our long-run model. To show this, in the second step of Engle-Granger co-integration test the unit root test is applied on the residuals series obtained from the regression. Table 3 reveals that the residual series $\left(\varepsilon_{t}\right)$ is stationary at level as it rejects the null hypothesis of unit root in level form with a significant p-values 0.000 at $1 \%$ level. Similarly, at level form the test statistic -5.733 in intercept and -5.706 in trend and intercept is greater than the Engle-Granger critical values -5.240 in intercept and 5.512 in trend and intercept at $1 \%$ level. Thus, the residual term is integrated of order zero $\mathrm{I}(0)$ showing the existence of co-integration among the variables.

\section{Error Correction Model}

ECM estimation result in Table 4 shows that the coefficient of the one term lagged error correction term $\left(\varepsilon_{t-1}\right)$ with -0.559 implying $55.9 \%$ of the shock/change in the rate of GDP is adjusted annually. This rapid speed of adjustment process is also evidenced from the significant $p$-value of the coefficient which satisfied the statistical significance of adjustment coefficient $\left(\varepsilon_{t-1}\right)$ in our model. Since, statistically significant CPY proves short run positive impact on RGDP. Meanwhile, the coefficients of M2Y, PIY, TOY and CPI in the error correction suffered from the problem of statistical insignificance.

Table 1: Augmented dickey fuller test results

\begin{tabular}{|c|c|c|c|c|c|}
\hline \multirow[b]{2}{*}{ Variables } & \multicolumn{2}{|l|}{ Level } & \multicolumn{3}{|l|}{ First difference } \\
\hline & Intercept & Trend and intercept & Intercept & Trend and intercept & integration \\
\hline LNRGDP & $-0.429(0.893)$ & $-1.268(0.880)$ & $-6.046^{*}(0.000)$ & $-5.842^{*}(0.000)$ & $\mathrm{I}(1)$ \\
\hline LNM2Y & $0.569(0.986)$ & $-2.253(0.448)$ & $-5.123^{*}(0.000)$ & $-4.860^{*}(0.001)$ & $\mathrm{I}(1)$ \\
\hline LNCPY & $-0.163(0.934)$ & $-2.670(0.254)$ & $-5.375^{*}(0.000)$ & $-5.295^{*}(0.000)$ & $\mathrm{I}(1)$ \\
\hline LNTOY & $-1.564(0.490)$ & $-1.742(0.712)$ & $-4.870^{*}(0.000)$ & $-4.844^{*}(0.001)$ & $\mathrm{I}(1)$ \\
\hline LNPIY & $-0.701(0.834)$ & $-3.226(0.093)$ & $-7.565^{*}(0.000)$ & $-7.556^{*}(0.000)$ & $\mathrm{I}(1)$ \\
\hline LNCPI & $-1.207(0.661)$ & $-1.391(0.847)$ & $-4.966^{*}(0.000)$ & $-5.016^{*}(0.001)$ & $\mathrm{I}(1)$ \\
\hline
\end{tabular}

H0: Has a unit root (non-stationary)

H1: Does not has a unit root (stationary)

*denotes rejection of the hypothesis at the $1 \%$ level. The values in the table are t-statistic and the values inside the parenthesis are probabilities

Table 2: OLS regression result

\begin{tabular}{lccc}
\hline Variable & Coefficient & Std. error & $t$-Statistic \\
\hline LNCPY & 0.109 & 0.040 & 2.670 \\
LNM2Y & -0.074 & 0.007 & -1.054 \\
LNPIY & 0.129 & 0.035 & 3.652 \\
LNTOY & -0.017 & 0.033 & -5.078 \\
LNCPI & 0.518 & 0.029 & 17.817 \\
C & 11.078 & 0.390 & 0.299 \\
R-squared & 0.998 & & 0.000 \\
Adjusted R-squared & 0.997 & & 0.000 \\
Prob. (F-stat) & 0.000 & & \\
Durbin-watson test & 1.613 & & \\
Dependent variable: LNRGDP & & \\
Method: Ordinary Least Square & &
\end{tabular}


Table 3: ADF test of residual series

\begin{tabular}{llcl}
\hline & Level form & & Order of integration \\
Variable & Intercept & Trend and intercept & $\mathrm{I}(0)$ \\
\hline$\varepsilon_{t}$ & $-5.733 *(0.000)$ & $-5.706 *(0.000)$ & \\
\hline $\begin{array}{l}\text { Engle-Granger critical values for } n=50, k=6 \text { are }-5.24,-4.70,-4.42 \text { and }-5.51,-4.97,-4.69 \text { for intercept, trend and intercept at } 1, \\
5 \text { and } 10 \% \text { level respectively }\end{array}$
\end{tabular}

Table 4: Error Correction Model (ECM)

\begin{tabular}{lllll} 
Variable & Coefficient & Std. error & t-statistic & Prob. \\
\hline D(LNCPY) & 0.109 & 0.054 & 1.996 & 0.054 \\
D(LNM2Y) & -0.098 & 0.086 & -1.135 & 0.264 \\
D(LNPIY) & 0.041 & 0.034 & 1.178 & 0.247 \\
D(LNTOY) & 0.006 & 0.053 & 0.112 & 0.911 \\
D(LNCPI) & 0.072 & 0.109 & 0.660 & 0.513 \\
C & 0.035 & 0.012 & 2.903 & 0.006 \\
$\varepsilon_{t-1}$ & -0.559 & 0.147 & -3.785 & 0.000 \\
\hline
\end{tabular}

\begin{tabular}{ll}
\hline R-squared & 0.381 \\
Adjusted R-squared & 0.265 \\
Durbin-watson stat & 1.615 \\
Dependent variable: D(LNRGDP) & \\
Method: Ordinary Least Square & Number of observation: 39 after adjustment
\end{tabular}

Table 5: Granger causality tests

\begin{tabular}{|c|c|c|c|c|}
\hline Null hypothesis & Lag 1 & Lag 2 & Lag 3 & Remarks \\
\hline DLNCPY does not granger & 0.01 & 0.22 & 1.80 & No causality \\
\hline Cause DLNRGDP & $(0.92)$ & $(0.79)$ & $(0.16)$ & \\
\hline DLNRGDP does not granger & 2.72 & $10.66^{*}$ & $6.26^{*}$ & $\mathrm{GDP} \rightarrow \mathrm{CPY}$ \\
\hline Cause DLNCPY & $(0.10)$ & $(0.00)$ & $(0.00)$ & \\
\hline DLNM2Y does not granger & 2.59 & 0.61 & $4.39 * *$ & $\mathrm{M} 2 \mathrm{Y} \rightarrow \mathrm{GDP}$ \\
\hline Cause DLNRGDP & $(0.11)$ & $(0.54)$ & $(0.01)$ & \\
\hline DLNRGDP does not granger & $3.15^{* * *}$ & $9.98^{*}$ & $5.63^{*}$ & $\mathrm{GDP} \rightarrow \mathrm{M} 2 \mathrm{Y}$ \\
\hline Cause DLNM2Y & $(0.08)$ & $(0.00)$ & $(0.00)$ & \\
\hline LNPIY does not granger & 1.15 & 0.69 & 0.60 & No causality \\
\hline Cause LNRGDP & $(0.29)$ & $(0.50)$ & $(0.61)$ & \\
\hline LNRGDP does not granger & $9.96 *$ & $3.76 * *$ & $4.78 *$ & $\mathrm{GDP} \rightarrow \mathrm{PIY}$ \\
\hline Cause LNPIY & $(0.00)$ & $(0.03)$ & $(0.00)$ & \\
\hline LNTOY does not granger & 0.00 & 0.02 & 0.05 & No causality \\
\hline Cause LNRGDP & $(0.98)$ & $(0.97)$ & $(0.98)$ & \\
\hline LNRGDP does not granger & 0.31 & 0.54 & 0.56 & No causality \\
\hline Cause LNTOY & $(0.57)$ & $(0.58)$ & $(0.64)$ & \\
\hline LNCPI does not granger & $7.45^{*}$ & $3.53 * *$ & $2.55 * * *$ & $\mathrm{CPI} \rightarrow \mathrm{GDP}$ \\
\hline Cause LNRGDP & $(0.00)$ & $(0.04)$ & $(0.07)$ & \\
\hline
\end{tabular}

Causality Test Between EG and FD Indicators Granger Causality Test

From the Table 5 it is observed that there is no causality in case of causal relationship between CPY and real GDP, whereas, causality runs in the opposite direction from real GDP to CPY when taking lags 2 and 3 having F-stats and corresponding p-values $10.66(0.00)$ and $6.26(0.00)$ but no causality in case of lag 1. F-stats and their respective p-values at third lag shows causality running from M2Y to real GDP. Meanwhile, the causality from real GDP to M2Y is bi-directional. In the case of real sector variables, no causality is observed between PIY and real GDP, whereas, causality runs in the opposite direction from real GDP to PIY when taking lags 1, 2 and 3 while referring F-stats and corresponding p-values. The study observed trade openness to GDP ratio has no causal relationship with real GDP. In the contrary, consumer price index and real GDP both have a significant causality between each other.

\section{Discussion}

The result of unit root test shows that RGDP, M2Y, CPY, TOY, PIY and CPI all are stationary at first difference. The results of the OLS model shows that 
there is weak long-run relationship of M2Y on RGDP while other independent variables CPY, PIY, TOY and CPI have significant long-run association with RGDP with only having negative relationship of M2Y and TOY with RGDP. Similarly, the results of unit root test of residual series $\varepsilon_{t}$ is stationary in level form with t-stats and corresponding p-values $-5.73(0.00),-5.70(0.00)$ in intercept, trend and intercept are significant at less than $1 \%$. The model predicts existence of co-integration among the variables GDP, CPY, M2Y, PIY, TOY and CPI. In addition, the ECM results conclude that there is only a significant and positive relationship between CPY and RGDP in the short-run depicting $0.10 \%$ change in RGDP with a $1 \%$ increase in CPY. The ECM estimation of lagged error correction term $\left(\varepsilon_{t-1}\right)$ also reveals that $55.9 \%$ of the annual disequilibrium adjustment, relatively a higher speed of adjustment depicting convergence in the model. Similarly, Granger causality test shows that M2Y and CPI have bi-directional causality with RGDP while CPY and PIY have unidirectional relation with feedback effect running from economic growth to private credit and private investment. But, TOY and RGDP have no causality.

Here, the credit to private sector to GDP ratio does not impact RGDP but instead the causality runs the opposite way supporting the demand following hypothesis of Patrick (1966) while the bidirectional causality between M2Y and RGDP supports both demand following and supply leading hypothesis (Odhiambo, 2007). The study finds both short run and long run association between credit to private sector (FD proxy) and RGDP (EG proxy) which is in agreement with explanation in a book of written by King and Levine (1993) and a study of Nepal (Gautam, 2014). However, broad money to GDP ratio is not found to be co-integrated in either short or long-run with economic growth in Nepalese context which limits the role of financial deepening in economic growth despite bidirectional causality evidenced by Granger causality test being different with the study of Tanjania (Odhiambo, 2011). Similarly, there is also a mixed result of real sector contribution in GDP as evidenced by positive role of PIY and CPI in GDP thus suggesting contractionary fiscal and monetary policies to induce private sector investment in GDP.

Although the role of inflation in economic growth is controversial, particularly this study predicts that mild inflation of $4-6 \%$ accelerates the economic growth in a demand-driven economies like Nepal, which is in agreement with a paper based in Nepal (Bhusal and Silpakar, 2005) who found positive relationship between inflation and economic growth in Nepalese context within the threshold value of $6 \%$ inflation. In addition, the study also predicts negative co-integrating relationship between trade openness and GDP, contrasting the result of 15 Asian countries (Nasreen and Anwar, 2014). Finance-led growth has some positive implications but the growth itself has more impact on financial development system and the real sectors like CPIwhich has more impact on real GDP than FD indicators (M2Y, CPY) in Nepal which supports the argument of growth led finance of recent studies (Gurley and Shaw, 2011; Ihsan, 2013). Growth therefore generally leads finance because of the increasing demand for financial services induced by economic growthin developing countries. Nevertheless, financial intermediation especially through credit creation helps to boost the short-run economic growth (McCaig and Stengos, 2005) and sustain the long-run growth as evidenced by positive relation between CPY and GDP through ECM. Thus, this study recommends that priority should be driven towards the development of real sector economy with equal focus on the development of FIs as both complement each other which is the mixed implication of Patrick's demand following and supply leading hypothesis (Patrick, 1966).

Through policy perspective, the priority should be given to deepen the financial sectors' accessibility, efficiency and integration with real sector. Meanwhile, the issues of financial governance, stability and regulation still remained a pertinent challenge in Nepalese financial market. It is necessary to undertake apposite measures to enhance the growth in both financial and economic activities considering the existence of bidirectional causality between financial development and economic growth in Nepal. Dependence on annual secondary data with the absence of quarterly data limits the number of observations and wider coverage of the research.

\section{Conclusion}

The study examined the relationship among proxies of financial development and real sector growth with economic growth in short run as well as long run and also predicts the direction of causality among these variables. Hence, results conclude that although financeled growth yields positive consequences but the growth itself affects the financial development system and real sectors like CPI has more impact on real GDP than financial development indicators (M2Y, CPY) in Nepal. This study also predicts negative co-integrating relationship between trade openness and GDP. Bidirectional causality between broad money to GDP ratio and real GDP and unidirectional causality of PIY and CPI with positive role upon GDP suggesting urgent need of contractionary fiscal and monetary policies to induce private sector investment in GDP. So, the priority should be driven towards the development of real sector economy with equal focus on the development of FIs as both complement each other. 


\section{Acknowledgement}

Authors acknowledge comments and suggestions from faculty members of Tribhuvan University.

\section{Author's Contributions}

Uttam Paudel and Umesh Khatri: Prepared and finalized manuscript.

Satish Chandra Bhatta: Collected and analyze the data.

\section{Ethics}

This article is original and contains unpublished material. The corresponding author confirms that all of the other authors have read and approved the manuscript and there are no ethical issues involved.

\section{References}

Arrow, K.J. and M. Kruz, 2013. Public Investment, the Rate of Return and Optimal Fiscal Policy. 1st Edn., Routledge, ISBN-10: 113598882X, pp: 218.

Asia, S., 2014. Finance sector reform in Nepal - what works, what doesn't'.

Bhusal, T.P. and S. Silpakar, 2005. Inflation and growth: Estimation of threshold point for. Eco. J. Dev. Issues, 13: 1-15.

De Gregorio, J. and P.E. Guidotti, 1995. Financial development and economic growth. World Dev., 23: 433-448. DOI: 10.1016/0305-750X(94)00132-I

Enders, W., 2014. Applied econometric time series. Technometrics, 46: 264-264. DOI: $10.1198 /$ tech.2004.s813

Engle, R.F. and C.W.J. Granger, 1987. Co-integration and error correction: Representation, estimation and testing. Econometrica, 55: 251-76.

DOI: $10.2307 / 1913236$

Gautam, B.P., 2014. Financial development and economic growth in Nepal. NRB Working Paper No. 25, Nepal Rastra Bank, Research Department.

Gurley, J.G. and E.S. Shaw, 2011. Intermediaries and monetary theory: A criticism of the Gurley-Shaw theory. Am. Eco. Assoc., 481: 132-138.

Ihsan, S.A., 2013. Impact of money supply (M2) on GDP of Pakistan. Global J. Manage. Bus. Res. Finance, 13: 2249-4588.

Jin, Y., 2010. Ch Ive. 19: 689-698.

King, R. and R. Levine, 1993. Finance and growth: Schumpeter might be right. Quarterly J. Eco., 108: 717-737. DOI: $10.2307 / 2118406$

Levine, R. and S. Zervos, 1996. Stock market development and long-run growth. World Bank Eco. Rev., 10: 323-339. DOI: 10.1093/wber/10.2.323
Levine, R., 1997. Financial development and economic growth: Views and agenda. J. Eco. Literature, 35: 688-726. DOI: 10.1126/science. 151.3712 .867 -a

Maskay, B.K., 2016. Financial development, human capital and economic growth - introduction: Importance of.

McCaig, B. and T. Stengos, 2005. Financial intermediation and growth: Some robustness results. Eco. Lett., 88: 306-312. DOI: $10.1016 /$ j.econlet.2004.12.031

Menyah, K., S. Nazlioglu and Y. Wolde-Rufael, 2014. Financial development, trade openness and economic growth in African countries: New insights from a panel causality approach. Eco. Modell., 37: 386-394. DOI: 10.1016/j.econmod.2013.11.044

Nasreen, S. and S. Anwar, 2014. Causal relationship between trade openness, economic growth and energy consumption: A panel data analysis of Asian countries. Energy Policy, 69: 82-91. DOI: 10.1016/j.enpol.2014.02.009

Nelson, C.R. and C.R. Plosser, 1982. Trends and random walks in macroeconmic time series: Some evidence and implications. J. Monetary Eco., 10: 139-162. DOI: 10.1016/0304-3932(82)90012-5

North, D.C., 1987. Institutions, transaction costs and economic growth. Economic Inquiry, 25: 419-428. DOI: $10.1111 / \mathrm{j} .1465-7295.1987 . t b 00750 . \mathrm{x}$

Odhiambo, N., 2011. Financial deepening, capital inflows and economic growth nexus in Tanzania: A multivariate model. J. Soc. Sci., 28: 65-71.

Odhiambo, N.M., 2007. Supply-leading versus demandfollowing hypothesis: Empirical evidence from three SSA countries. Afr. Dev. Rev., 19: 257-280. DOI: $10.1111 /$ j.1467-8268.2007.00161.x

Patrick, H.T., 1966. Financial development and economic growth in underdeveloped countries and economic growth financial development in underdeveloped. Chicago J., 14: 174-189.

Rousseau, P.L. and P. Wachtel, 2011. What is happening to the impact of financial deepening on economic growth?. Eco. Inquiry, 49: 276-288.

DOI: $10.1111 /$ j.1465-7295.2009.00197.x

Samargandi, N., J. Fidrmuc and S. Ghosh, 2015. Is the relationship between financial development and economic growth monotonic? Evidence from a sample of middle-income countries. World Dev., 68: 66-81. DOI: 10.1016/j.worlddev.2014.11.010

Team, E. and P. By, 2013. SEBON Journal.

Thiel, M. and M. Thiel, 2001. Finance and economic growth: A review of theory and the available evidence. European Communities, Commission, Directorate General for Economic and Financial Affairs, Economic Papers.

Timsina, N., 2014. Impact of bank credit on economic growth in Nepal. 